¡Un momento, SeÑor Andersen! (1840)

Søren Kierkegaard

Fuente:

Søren Kierkegaard, “Et Øieblik, Hr. Andersen!”, en Af Søren Kierkegaards Efterladte Papirer, 1833-1843, ed. por Hans Peter Barfod, Copenhague: C. A. Reitzels Forlag, 1869, pp. 267-271.

Notas y traducción del danés de F. Nassim Bravo Jordán 



\title{
¡Un MOMENTO, SEÑor Andersen! (1840)
}

\author{
Søren Kierkegaard
}

Se cuenta de Till Eulenspiegel ${ }^{1}$ que su patrona lo mandó a la ciudad por 4 $\beta^{2}$ de vinagre. Se ausentó casi por tres años. Hacia el final del tercer año, entró precipitadamente por la puerta, hizo pedazos la botella, derramó el vinagre y exclamó: “ ¡El diablo ha creado las prisas!” ${ }^{3}$ De forma más o menos parecida, el señor Andersen, para no poco susto mío, ha entrado de forma precipitada al mundo literario con $4 \beta$ de polémica, los cuales probablemente ha reunido con esmero durante los dos años transcurridos desde que tuve esa ocurrencia ${ }^{4}$ que ahora es castigada con tanta dureza.

Pero primero un par de datos históricos que serán absolutamente necesarios para el público lector, pues en este instante soy incapaz de escribir acerca del poeta Andersen, célebre a lo largo y ancho de Europa, y quien dentro de poco emprenderá su marcha triunfal ${ }^{5}$ sin prestar atención a mi insignificante persona. A saber, doy por supuesto que el público ya desde hace mucho ha olvidado, o quizá sea mejor decir que nunca supo que en el año de 1838 publiqué una pequeña obrita ${ }^{6}$ en la que, en la medida de mis capacidades, me esforcé por capturar la enredosa y abigarrada existencia poética anderseniana con todos sus recodos, meandros, virajes, contorsiones y torceduras. En el verano de 1840 se representó en el Teatro Real una pieza

${ }^{1}$ Till Eulenspiegel o, en danés, Till Ugelspegel, figura legendaria de la Edad media proveniente del norte de Alemania. Eulenspiegel, como se lo suele representar en fuentes orales o escritas, es un bromista itinerante que expone y se burla de la necedad burguesa.

${ }^{2}$ B, skilling, es decir, cuartos. A partir de un decreto del 31 de julio de 1818, la moneda danesa se dividió en táleros (rigsdaler), marcos (mark) y cuartos (skilling). Un tálero equivalía a 6 marcos, un marco a 16 cuartos y un tálero a 96 cuartos.

${ }^{3}$ La fuente de esta anécdota sobre Eulenspiegel no ha sido identificada.

${ }^{4}$ Es decir, la de escribir una reseña acerca de la última novela de Andersen, Apenas un músico. Kierkegaard publicó su crítica, Sobre los papeles de alguien que todavía vive, el 7 de septiembre de 1838, casi un año después de la aparición de la novela de Andersen (22 de noviembre de 1837).

${ }^{5}$ En 1840, Andersen recibió un apoyo real para realizar un largo viaje por el extranjero. La fecha de su partida, de acuerdo con los registros de la ruta hacia Kiel publicados en el diario Berlingske Tidende, fue el 31 de octubre de ese mismo año.

${ }^{6}$ Es decir, De los papeles de alguien que todavía vive. 
llamada Una comedia al aire libre. ${ }^{7}$ No hace falta ningún recordatorio de esto, pues la pieza era de Andersen. No obstante, precisamente durante ese verano trabajos más duros ${ }^{8}$ me impidieron mantenerme al tanto de las últimas producciones literarias, y tal vez yo, en mi aislada vida, hubiera permanecido ignorante de la existencia de dicha obra, de no ser porque un par de conocidos míos, quizá interesándose por mí —o, más bien, interesándose por lo cómico y por su delei ante mi apuro-, me contaron que existía; en efecto, que Andersen —y este es justo el meollo del asunto¡había puesto en boca de uno de los personajes largos discursos completos provenientes de mi pequeña obra! ${ }^{9}$ Esto fue demasiado. Todo se me oscureció. Con todo, no podía yo contener el deseo de obtener información un poco más precisa acerca del modo en que Andersen me había citado. Tenía la esperanza de que la dirección del teatro hubiera comprado la pieza de Andersen; ${ }^{10} \mathrm{y}$, de forma incomprensible, en verdad incomprensible: cuando esto no pasó, jamás se me ocurrió entonces aquello que era por demás obvio, que podía haberla comprado yo y habérsela obsequiado a la dirección del teatro —en el caso, desde luego, de que la quisiera—, para, de ser posible, obtener algún mérito por parte de las bellas artes, para, de ser posible, dar una prueba de que, con todo, hay también algunos que saben valorar a un poeta. Pero qué ocurre: mi deseo iba a cumplirse de otro modo, y esto precisamente cuando empezaba ya a renunciar a él, pues sabía que la partida de Andersen se acercaba a paso acelerado. Me hundí en una callada melancolía. Pensé para mis adentros: ahora se va Andersen;

${ }^{7}$ En Comedie i det Grønne, Vaudeville i een Akt efter det gamle Lystspil: Skuespilleren imod sin Villie [Una comedia al aire libre, vodevil en un acto basado en el drama cómico "El actor en contra de su voluntad"], con música de Edvard Helsted, fue estrenada en el Teatro Real de Copenhague el 13 de mayo de 1840. El texto del vodevil se publicó en el repertorio del Teatro Real [Det kongelige Theaters Repertoire, no. 124, vol. 6] el 26 de octubre de 1840. Kierkegaard compró una copia de la obra al día siguiente de su publicación.

${ }^{8}$ Kierkegaard se refiere, en primer lugar, a la preparación para su examen de teología en la Universidad de Copenhague, el cual se celebró el 3 de julio de 1840. Dos semanas después, el 18 de julio, Kierkegaard viajó a Jutlandia, de donde no regresaría sino hasta el 7 de agosto.

${ }^{9} \mathrm{El}$ personaje que reproduce las frases de De los papeles de alguien que todavía vive es Dalby, "el director de escena", quien aparece también disfrazado como un "peluquero". La mayoría de estos pasajes ocurren en la cuarta escena, en la conversación entre Dalby y Frank, "el inspector".

${ }^{10}$ En 1840, la dirección del Teatro Real estaba conformada por Christian Molbech y Joachim Godsche von Levetzau. El vodevil de Andersen fue duramente criticado por Molbech, quien la calificó como una mera farsa. No obstante, tiempo después el Teatro sí compraría la pieza. 
tal vez a Trebisonda o, que me lleve el diablo, a R...;1 quién sabe si alguna vez vuelva y, no obstante, nos hace falta esa pequeña pieza y en ella, quizás, una aportación muy considerable para hacer una descripción de su carácter. Ya había pensado en que le rogaría a través del diario que la publicara y, justo como suele leerse que alguna familia que está de paso le solicita a la dirección del teatro que represente una obra, así también yo como residente pienso estar, de la misma forma, autorizado para pedirle al ausente Andersen que cure y mitigue esta carencia por largo tiempo padecida publicando esta obra dramática. Pero tal vez fue algo bueno que no lo hiciera. La pieza habría perdido algo de la sorpresa, algo de la fragancia que guarda cuando se sabe que ninguna consideración temporal o terrena la ha llamado al mundo sino "la interior y profunda necesidad de lo poético". ${ }^{12}$ Aquello que incluso en mayor medida fue causa de que deseara que esta pieza fuera publicada, fue que esperaba, posiblemente, encontrar ahí una explicación más profunda acerca de un par de cosas que, en el momento de escribirlas, no me resultaron del todo claras.

Pero ¡ay, ay, ay! ¡Qué desventurados somos los seres humanos! Incluso 269 en Andersen la busqué: en vano. Se esfumaron mis sueños poéticos. De mi alma se apoderó una secreta sospecha de que hubiera sido otro el motivo por el que el teatro no la aceptara, un silencioso temor de que la causa de su actual publicación pudiera ser otra que el imperativo categórico del genio.

Me detendré en particular en este último punto. El poeta $\mathrm{Holst},{ }^{13}$ tal vez por circunstancias externas fuera del poder del atacante, se convirtió, algunos pocos días antes de su partida, en el objeto de un ataque ${ }^{14}$ que, precisamente

11 “A Trebisonda o, que me lleve el diablo, a R(uan)". La expresión es una paráfrasis de un pasaje del segundo acto de la comedia de Ludvig Holberg, Mester Gert Westphaler, eller den meget talende Barbeer [El maestro Gert Westphaler, o el barbero parlanchin], donde Gunild le dice a Gert, quien siempre habla de su viaje a Kiel: "Anders Christensen ha estado tres o cuatro veces en Burdeos y Ruan, en Francia, sí, que me lleve el diablo, hasta en Trebisonda o Cattesund, pero no habla ni remotamente tanto acerca de sus viajes". Cfr., Ludvig Holbergs udvalgte Skrifter [Escritos escogidos de Ludvig Holberg], ed. por K. L. Rahbek, vols. 1-21, Copenhague: Schultz, 1804-1814; vol. 6, 1806, p. 180.

${ }^{12}$ No se ha encontrado la fuente de esta cita.

${ }^{13}$ Hans Peter Holst (1811-1893), autor y poeta danés, fue también compañero de Kierkegaard en el colegio. Al igual que H. C. Andersen, Holst recibió un apoyo de la corona para realizar un viaje por el extranjero, el cual comenzó, de acuerdo con el registro de los pasajeros del buque de vapor Frederik VI, con rumbo a Kiel, el 15 de octubre de 1840.

${ }^{14}$ Holst fue acusado de plagio por Leonhard Groth — pseudónimo del literato islandés Grimur Thorgrimsson Thomsen (1820-1896) — en el artículo H. P. Holst et Bidrag til den nyere danske Litteraturbistorie [H. P. Holst, una contribución a la más reciente historia de 
debido a lo desfavorable de los tiempos, despertó el descontento con el autor. Conmigo es distinto. Pocos días antes de la partida de Andersen me volví objeto de un ataque ${ }^{15}$ (que ya había sido atacado durante el verano ${ }^{16}$ es algo que no puedo saber con total seguridad, pues las noticias eran sumamente enigmáticas; responder, por tanto, me resultaba imposible, de modo que había que considerar toda la maquinación de Andersen como una tentativa inútil). Él probablemente ya se había ido a encargar unos zapatos con suela de gamuza que pudieran resistir el viaje y, antes de que se supiera una palabra al respecto, tal vez él había partido.

Pero volvamos a nuestro asunto. En esta comedia aparece el director de escena Dalby haciendo distintos papeles, entre otros también el de un peluquero. Esta es la única representación con la que tengo que ver. Se supone que este personaje es un hegeliano parlanchín. Si ahora le dijera a Andersen que yo jamás me hecho pasar por un hegeliano y que, en ese sentido, era una necedad de su parte tomar frases de mi pequeña obra para ponerlas en boca de un hegeliano, entonces casi me parecería que estoy loco. Porque o bien tendría que relacionar la palabra "hegeliano" con la idea de un hombre que con gravedad y energía ha comprendido la visión de mundo de este pensamiento, que se ha dedicado a él, que ha encontrado reposo en él, y si ahora con un cierto orgullo genuino dijera acerca de mí mismo: "También 270 yo he tenido el honor de servir bajo Hegel”, en ese caso sería una insensatez de mi parte mencionar esto en una conversación con Andersen, ya que él probablemente no sería capaz de formular un pensamiento inteligente al respecto y, de forma parecida, yo al menos lo pensaría dos veces antes de emplear un calificativo tan significativo con relación a mí mismo, incluso si estuviera consciente de que me había esforzado por familiarizarme con la filosofía de Hegel. O bien por hegeliano entendería a un hombre que, interesado de forma superficial por esta filosofía, se engaña ahora con un resultado que no posee, y entonces no sería menos necio decirle esto a Andersen, en el supuesto de que se me dé la razón en que aquel que no sabe lo que en verdad es un hegeliano tampoco sabe lo que en falsedad es

la literatura danesa], Copenhague: (sin editorial), 1840, cuya publicación fue anunciada en el Berlingske Tidende el 16 de octubre de 1840, es decir, un día después de la partida de Holst.

${ }^{15}$ A saber, en la referida comedia de Andersen. Mientras que en el caso de Holst fue el atacado quien salió de viaje, en el caso de Kierkegaard, por el contrario, fue el atacante -Andersen- quien partía.

${ }^{16}$ El ataque tuvo lugar poco antes del verano, pues la comedia de Andersen se representó en el Teatro Real el 13 de mayo de 1840. 
un hegeliano, es decir, no podría haber ninguna idea concreta al respecto.

Por otra parte, yo, en un ánimo de completa transigencia, le informaré a Andersen de una ventaja que él posee, quizá sin que él mismo en verdad sepa en qué gran medida la posee. A saber, cuando uno desea poner una tontería en boca de alguien, para el escritor y poeta (no tanto para el lector), esto puede lograrse de dos modos: o uno, en virtud de la razón y con auxilio de su superioridad, mira desde arriba la vaga riqueza de la tontería, o se toma algo que uno no entiende y calladamente se formula la siguiente conclusión: si yo no lo entiendo, entonces es una tontería (y digo "calladamente" porque no siempre es recomendable decir esto en voz alta), y, enseguida, la copia o, mejor dicho, la dibuja, que es, desde luego, lo que siempre tienen que hacer aquellos que van a copiar algo que no entienden. A este respecto, le reconozco de buen grado a Andersen una excelencia por encima de todos los poetas que aún viven y lo felicito por el desmesurado común científico que se extiende frente a sus ojos, y lo único que me extraña es que él haya querido elegir mi pobre palmo de tierra, él, el poeta Andersen, que es el propietario negativo y monopolizado de toda filosofía y de toda la más elevada erudición, señor de ellas en el mismo sentido en "que los vagabundos se llaman a sí mismos señores de los palacios". ${ }^{17}$

Pero alguno que haya escuchado o leído esta comedia quizá dirá: ¿en verdad son citas esas palabras que Andersen pone en boca del peluquero? Dicha pregunta me parece la más natural del mundo, porque Andersen es el único que —algo sumamente halagüeño para mí - sigue convencido de que el público lector y aficionado al teatro no solo ha leído mi pequeña obra, sino que no la ha olvidado en dos años. Y en verdad este halago sabe dulce en mi boca, más dulce que la miel, pues no conozco nada más dulce que cuando alguien halaga en contra de su voluntad. Pero mi momentáneamente ausente entendimiento ha regresado otra vez y en verdad me doy cuenta de que tiene que haber un malentendido en el fondo, y Andersen, quien tal vez ha creído con cierta inquina que yo, por medio de esta pequeña obra, pretendía ligarme a su inmortalidad, ha querido asegurarme la imposibilidad de poder llegar a ser olvidado en algún momento. Si en verdad se trata de citas, me parece complicado demostrárselo al lector, ya que este, naturalmente, no tiene la obra a la mano, pero puedo asegurarle que, por ejemplo, la frase “ese sublimado que es la alegría de vivir", etcétera, que se encuentra en

${ }^{17} \mathrm{La}$ imagen de los vagabundos como señores de los palacios proviene de la obra de Andersen, Billedbog uden Billeder [El libro de imágenes sin imágenes], Copenhague: C. A. Reitzel, 1840, pp. 44, 47. 
la página tres, primera columna, ha sido copiada palabra por palabra, y lo único con lo que Andersen ha querido convertirla en propiedad suya —algo que para los más finos observadores de Andersen no es desafortunado- es que él escribe "matematica" sin la "h".

Esto debe ser suficiente por ahora.

Si Andersen quisiera continuar con esta polémica, entonces yo, a fin de no recargar los diarios con mis insignificantes papeleos, le propongo que publiquemos un periódico en conjunto, y para no tener nada que reprocharme por ocasionarle un gasto, estoy más que dispuesto a encargarme de la parte económica, tanto más cuanto que, de acuerdo con nuestra administración de justicia, el perdedor siempre es sentenciado a correr con los gastos del proceso. Solo algo deseo pedirle: que como compensación por haberse tardado dos años para su primera exposición, al menos ofrezca su respuesta con la suficiente anticipación antes de su partida, para que yo tenga un par de horas para elaborar mi propia respuesta, la cual podrá estar en sus manos antes de su viaje, porque este asunto no es de tal naturaleza que a mí me interese escribir al respecto una vez que Andersen haya dejado Copenhague. 